\title{
Patterns of resting site use by pine marten Martes martes in Białowieża National Park (Poland)
}

\author{
Andrzej ZALEWSKI
}

Zalewski A. 1997. Patterns of resting site use by pine marten Martes martes in Białowieża National Park (Poland). Acta Theriologica 42: 153-168.

Use of resting sites by 14 radio-tracked pine martens Martes martes (Linnaeus, 1758) (6 males and 8 females) was studied in Białowieża National Park, northeastern Poland. Males used, on average, 191 different resting sites throughout the year while females used 159 sites. The reuse index varied from 0.07 to 0.94 and it was highest for females with young in spring and lowest for both males and females in summer. In autumn-winter, reuse of resting sites by males decreased significantly $(p=0.006)$ in deep snow cover and it increased $(p=0.021)$ when marten's ate more ungulate carcasses. In spring, the reuse index for males was negatively correlated with the mean ambient temperature during the tracking period $(p=0.019)$ and did not depend on rodent abundance. In spring and autumn-winter, most individuals used resting sites which were randomly distributed in their home ranges. In summer, resting sites of males were clumped and were located near the edges of their home ranges, close to females' home ranges. The average distance between consecutively used resting sites was significantly higher for males $(690 \mathrm{~m})$ compared to females $(419 \mathrm{~m}$, $p<0.001$ ). In spring and autumn-winter (but not in summer) the average distance between the male resting sites depended on their body mass. For males, temperature had significant influence on the pattern of resting site choice for the following day, while for females this relationship was not found. Individuals of the same sex and overlapping home ranges did not use the same resting sites in the same season, except for a young male and an old female that were found in one resting site at the same time from mid-June to mid-August.

Mammal Research Institute, Polish Academy of Sciences, 17-230 Białowieża, Poland; e-mail: zalewski@bison.zbs.bialowieza.pl

Key words: Martes martes, resting site, mating tactics, radio-telemetry, home range use, social interactions

\section{Introduction}

Martens are mostly active during the night (Zielinski et al. 1983, Skirnisson 1986, Marchesi 1989), while the day is spent at a resting site. These sites are important for two reasons: firstly, martens have a long body and need to reduce heat loss which they can do by choosing well insulated resting sites (Buskirk et al. 1989, Brainerd et al. 1995, Zalewski 1997). Secondly, martens are medium-sized predators and can be killed by other larger predators (Lindström et al. 1995, Okarma et al. 1997). They can reduce their predation risk by choosing the most secure places on the tree. During the whole year, energetic factors and predation risk are the main factors affecting the choice of the type of resting site used by 
martens. As has been shown for other mustelids, lower numbers of resting sites of sufficient quality can decrease density (Beja 1996, Halliwell and Macdonald 1996) and can also increase the intraspecific competition for this resource. Not only does the availability of resting sites have an important role in relation to overall density, but the distribution of sites in the home range can minimize distance between the resting site and foraging areas (Weber 1985) or between the male resting sites and receptive females.

Białowieża National Park protects the last natural deciduous and mixed forest in lowland Europe where the average age of a tree stand is 130 years. Tree cover is dense, and the number of natural cavities is relatively high, many resulting from the high number of woodpeckers (eight species found here). The red squirrel Sciurus vulgaris also occurs and the number of dreys are very high in some years (W. Jędrzejewski, unpubl.). Fallen logs on the forest floor also provide natural cavities. Natural cavities, woodpecker holes, squirrel dreys and log cavities comprise optimal habitat with many potential resting sites for pine marten. Therefore, the forests of Białowieża National Park offer a good opportunity to study the natural patterns of spatial use (and need) of resting sites by pine marten as well as the factors affecting that pattern.

In this study I analyzed the following problems: (1) the number of resting sites used by pine martens in a long-term scale, (2) factors affecting the reuse of resting sites, (3) the spatial distribution of resting sites and their seasonal pattern of use, and (4) relationships between individuals utilizing a common resting site.

\section{Study area}

Białowieża National Park (BNP) is the last remnant of the pristine European lowland forests. It is situated in north-eastern Poland close to the Polish-Byelorussian border $\left(52^{\circ} 43^{\prime} \mathrm{N}, 23^{\circ} 54^{\prime} \mathrm{E}\right)$ and covers an area of $47.5 \mathrm{~km}^{2}$. The strictly protected BNP is a part of the extensive forest complex of Białowieża Primeval Forest $\left(1,250 \mathrm{~km}^{2}\right)$. It contains three main forest types: oak-lime-hornbeam (Tilio-Carpinetum), mixed coniferous (Pino-Quercetum, Peucedano-Pinetum) and ash-alder tree stands (Circaeo-Alnetum, Carici elongate-Alnetum). Oak-lime-hornbeam stands cover $44.4 \%$ of the whole area and are composed of hornbeam Carpinus betulus, oak Quercus robur and lime Tilia cordata with admixture of spruce Picea abies. On wet river or stream margins, characterized by damp soils, the dominating tree stands are alder Alnus glutinosa, ash Fraxinus excelsior and spruce. On sandy soils the dominant tree stand is mixed coniferous forest with spruce and pine Pinus sylvestris. Detailed information on the vegetation of BNP is given by Faliński (1986).

The climate of BNP is of a transitional character, with continental features dominant (Olszewski 1986). During the study period (April 1991 - March 1996) average January and February daily temperatures varied from -8.5 to $2.2^{\circ} \mathrm{C}$ (the lowest day time temperature at $07.00 \mathrm{~h}$ in the study period was $-24.6^{\circ} \mathrm{C}$ ). Snow cover varied from 0 to $63 \mathrm{~cm}$. The warmest month was July, with average temperatures varying from 16.8 to $22.5^{\circ} \mathrm{C}$ (the daytime maximum temperature was $28.7^{\circ} \mathrm{C}$ ).

\section{Material and methods}

From April 1991 to March 1996 fourteen pine martens were caught by live box traps, using eggs, honey or meat as bait. Trapped martens were fitted with $12-25$ g radio-collars (AVM or Lotek) and 
released at the trapping sites. Martens were then located at the resting sites between $07.00-17.00 \mathrm{~h}$ when they were mostly inactive (Marchesi 1989, A. Zalewski, unpubl.). The positions of resting sites were measured by steps in relation to forest grid. All the resting sites were marked with tape on which the date (when it was found there for the first time) and the identification number of individual pine marten were written. The index of reuse of resting sites (RI) was calculated as follows:

$$
\mathrm{RI}=1-(\mathrm{Ds} / \mathrm{Ts})
$$

where: Ds - number of different resting sites, Ts - total number of days (localizations) when a marten was found in resting site. The index varies from 0 , when the marten uses a new resting site each time, to 1 , when the marten uses one resting site continuously for the whole season. I defined three survey seasons each year: spring (16 March to 15 June), summer (16 June to 15 October), and autumn-winter (16 October to 15 March).

The influence of weather conditions and diet composition on utilisation of resting sites was analysed. Meteorological data were provided by the Białowieża Meteorological Station. An index of rodent abundance was calculated from the long-term removal trapping of small mammals in the oak-lime-hornbeam forest in BNP (Pucek et al. 1993, and Z. Pucek, unpubl.). During the autumn-winter season, scats were collected from the resting sites of each marten and on snow tracks of the collared individuals. A total of 540 scats were collected and analysed following standard procedures (Lockie 1959, Goszczyński 1974). For more detailed information see also Jędrzejewski et al. (1993). Male M7 (see Table 1) was excluded from the analysis of the influence of weather conditions and diet composition on the resting site reuse index because it was a young individual without a stable home range. For the same reason male M7 was excluded from the analysis of the relationship between resting site distance and marten body mass.

Table 1. Numbers of resting sites used by pine martens Martes martes in Białowieża National Park (Poland). Number of resting site calculated for one year was done for martens radio-tracked for longer than one season.

\begin{tabular}{|c|c|c|c|c|}
\hline \multirow[b]{2}{*}{ Martens } & \multirow[b]{2}{*}{ Observation period } & \multirow{2}{*}{$\begin{array}{c}\text { Number } \\
\text { of localizations } \\
\text { in resting sites }\end{array}$} & \multicolumn{2}{|c|}{ Number of resting sites } \\
\hline & & & Different & $\begin{array}{c}\text { Calculated for } \\
\text { one year }\end{array}$ \\
\hline M1 & $21.04 .93-28.04 .93$ & 5 & 4 & - \\
\hline M3 & $12.10 .93-15.03 .95$ & 216 & 118 & 199.4 \\
\hline M4 & $12.05 .91-19.03 .92$ & 209 & 107 & 186.9 \\
\hline M5 & $31.01 .92-14.03 .96$ & 491 & 244 & 181.4 \\
\hline M7 & $06.12 .94-28.08 .95$ & 178 & 96 & 196.8 \\
\hline M10 & $24.10 .94-25.02 .95$ & 80 & 27 & - \\
\hline Average for males & & & & $\begin{array}{c}191.1 \\
(\mathrm{SD}=8.43)\end{array}$ \\
\hline $\mathrm{F} 1$ & 08.05.92-13.04.94 & 48 & 18 & 136.9 \\
\hline F2 & 13.04.91-15.04.91 & 2 & 2 & - \\
\hline F6 & 19.11.91-16.12.93 & 159 & 89 & 204.3 \\
\hline F8 & $27.03 .92-16.05 .94$ & 62 & 21 & 123.6 \\
\hline F9 & $16.02 .95-19.07 .95$ & 81 & 36 & 162.2 \\
\hline F11 & 17.11.95-21.02.96 & 52 & 23 & - \\
\hline F12 & $27.02 .95-16.02 .96$ & 189 & 87 & 168.0 \\
\hline F33 & $09.05 .92-02.06 .92$ & 18 & 5 & - \\
\hline Average for females & & & & $\begin{array}{c}159.0 \\
(\mathrm{SD}=31.16)\end{array}$ \\
\hline
\end{tabular}


The distribution of resting sites was analysed in relation to an individual's home range. Home ranges were plotted by Minimum Convex Polygon (MCP) using all active relocations and the first record at each resting site during the inactive period for each season in various years. The distribution of different resting sites in home range within a grid $(200 \times 200 \mathrm{~m})$ was calculated using the standardized Morisita coefficient of dispersion (Ip) (Krebs 1989). A coefficient was -1 if the distribution was uniform, 0 if the distribution was random, 1 if the distribution is aggregated (clumped). The influence of female spatial pattern on the resting site used by males during summer was analysed. In summer 1991, home range distribution of females older than 2 years was determined based on radiotracking done in spring 1992. This was possible because female's fidelity from season to season was very high (A. Zalewski and W. Jędrzejewski, in prep.). In two cases observations of females with young were used. The distribution of females was also plotted by snow tracking since the measurement of tracks enabled one to distinguish between sexes and females (A. Zalewski, in prep.). The areas of frequently used resting sites were plotted using all the cases when the martens were localised in the resting site in a given season. For this aim the Kernel estimator (for $75 \%$ of resting sites) was used (Tracker computer program).

\section{Results}

\section{Number and reuse of resting site}

Male martens were found on average 197 times $(\mathrm{SD}=166)$ in $99.3(\mathrm{SD}=84)$ different resting sites (Table 1). Females were found on average 76 times $(\mathrm{SD}=65$ ) in $35(\mathrm{SD}=34)$ resting sites. For all tracked individuals the number of different resting sites used by marten increased throughout the study period (Fig. 1). On average, males used one resting site 1.95 times and females 2.18 times. For

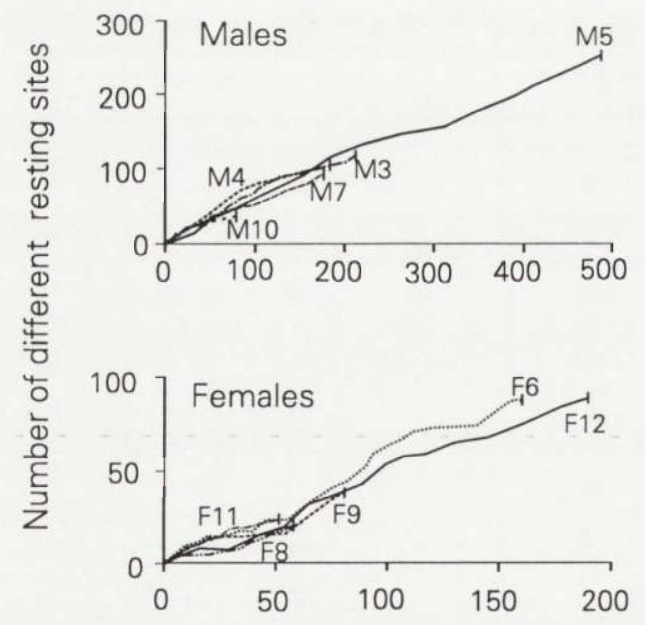

Number of all localizations in resting sites

Fig. 1. Increase of the number of different resting sites used by pine martens in Białowieża National Park with increasing total number of localizations (days) of martens in the resting sites. individuals tracked longer than one season the number of resting sites used throughout a year (365 days) was calculated. On average, males used 191 different resting sites and females 159 sites. These values did not differ significantly (Mann-Whitney test, $U=16, n=9$, ns).

The number of used resting sites varied among seasons and reuse indices calculated for each individual in each season varied from 0.07 to 0.94 . The highest reuse index was that for females with young in spring (Fig. 2). During that time, females used one natal site for long periods and throughout spring they needed only about 20 different sites (Table 2). Furthermore, females with young used different resting sites less often 
than females without young. In spring reuse of resting sites by males was significantly lower than by females, both with and without young (Fig. 2). Reuse by males during this season was also lower than in autumn-winter $(U=41, n=14, p=0.014)$. During spring, males used 64 different resting sites and females without young 48 sites. In summer both males and females used more resting sites and their reuse indices were lower. Differences in reuse indices between males and females were not significant in either summer or autumn-winter (Fig. 2). But males and females reused resting sites more often during autumn-winter than during summer (in males $U=45, n=14, p=0.003$; in females $U=12, n=7, p=0.032$ ).

In autumn-winter reuse index varied between individuals and years from 0.44 to 0.56 in females and from 0.37 to 0.67 in males (Fig. 2). The greater variation in the reuse index in males depended on the mean snow depth of the tracking period (Fig. 3). When the snow was deep martens did

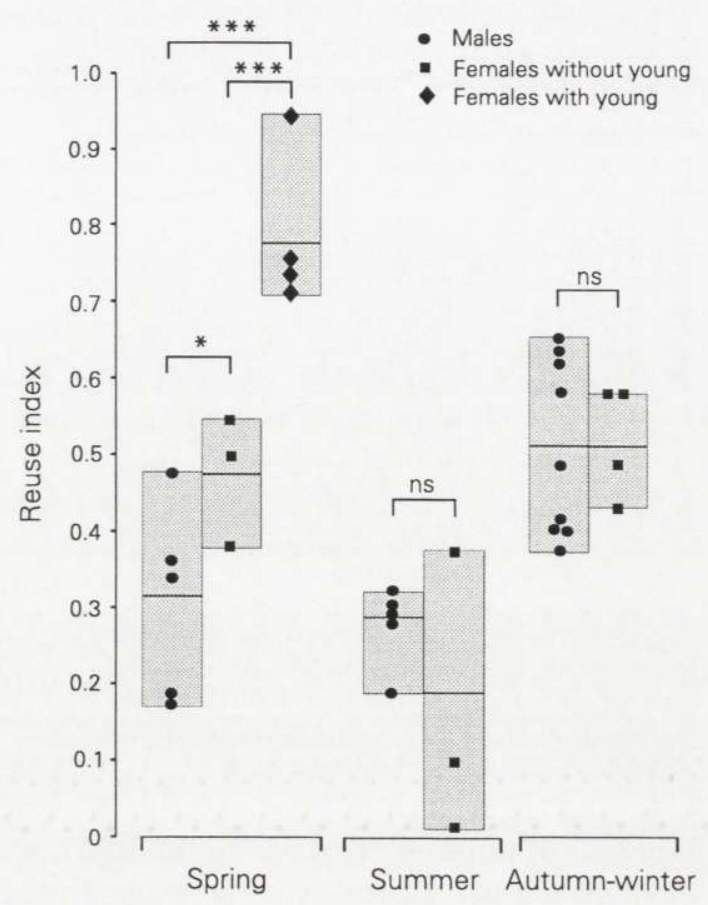

Fig. 2. Comparison of resting site reuse between male pine martens and females with and without young during three seasons. Each point = value for one individual in one season. Vertical shaded bars show the range of variation, and horizontal black lines are mean values in each class of individuals. Mann-Whitney test for comparing classes of individuals: ${ }^{*}-p<0.05,{ }^{* * *}-p<0.001$.

Table 2. Average values of reuse index of resting sites and calculated number of different resting sites used per season [calculated as: Number of days in a season $\times(1-$ Reuse Index)] by pine martens. Spring - 16 March to 15 June (92 days), summer - 16 June to 15 October (122 days), and autumn-winter - 16 October to 15 March (151 days).

\begin{tabular}{|c|c|c|c|c|c|c|}
\hline \multirow{2}{*}{ Season } & \multicolumn{2}{|c|}{ Males } & \multicolumn{2}{|c|}{ Females without young } & \multicolumn{2}{|c|}{ Females with young } \\
\hline & $\begin{array}{l}\text { Reuse } \\
\text { index }\end{array}$ & $\begin{array}{c}n \text { of resting } \\
\text { sites }\end{array}$ & $\begin{array}{l}\text { Reuse } \\
\text { index }\end{array}$ & $\begin{array}{c}n \text { of resting } \\
\text { sites }\end{array}$ & $\begin{array}{l}\text { Reuse } \\
\text { index }\end{array}$ & $\begin{array}{c}n \text { of resting } \\
\text { sites }\end{array}$ \\
\hline Spring & 0.30 & 64.4 & 0.48 & 47.8 & 0.78 & 20.2 \\
\hline Summer & 0.28 & 87.8 & 0.19 & 98.8 & - & - \\
\hline Autumn-winter & 0.51 & 74.0 & 0.51 & 74.0 & - & - \\
\hline
\end{tabular}




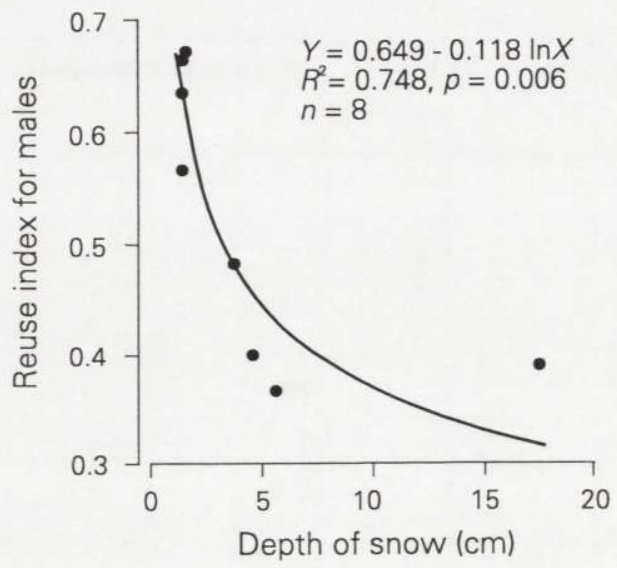

Fig. 3. Relationship between snow depth (average for the tracked days) and reuse of resting sites by male martens in Białowieża National Park. Each point represents one individual during one winter season.
A. Zalewski

not return to their old resting site. Besides snow depth, site reuse was also correlated with percentage biomass of ungulate carcasses in the male's diet in autumn-winter $\left(R^{2}=0.62, n=8, p=0.021\right)$, but neither with the autumn index of rodent abundance $\left(R^{2}=0.03, n=8, \mathrm{~ns}\right)$ nor with percentage biomass of rodents in marten diet $\left(R^{2}=0.01, n=8, \mathrm{~ns}\right)$. Male martens which ate more deer or wild boar carcasses stayed longer in or more often returned to a particular resting site located close to the carcass. Multiple regression analysis using both snow cover and percentage of ungulate carcass biomass in marten diets explained $80 \%$ of total variation in resting site reuse index and semipartial correlations showed that snow depth was more important $\left(s r^{2}=0.67\right)$ than percentage biomass of ungulate carcass in the marten diet $\left(s r^{2}=0.03\right)$ in influencing the reuse of resting sites. During spring, reuse index by males was negatively related to the mean ambient temperature of the tracking period $\left(R^{2}=0.96, n=4, p=0.019\right)$ and did not depend on rodent abundance in this season $\left(R^{2}=0.30, n=4\right.$, ns). Males often returned to the same resting site when the ambient temperature was lower.

\section{Distribution and pattern of use of resting sites}

In spring and winter most individuals used resting sites which were randomly dispersed in their home ranges (Fig. 4). The standardized Morisita coefficient of resting site dispersion in the home range varied from -0.24 to 0.50 (Table 3 ). In spring and winter, $75 \%$ of marten localizations in resting sites were distributed mainly in the central part of their home ranges (Fig. 4). The distribution of resting sites in summer had a pattern different from that in spring and winter. In summer, most of the tracked individuals used resting sites which were clumped (standardized Morisita coefficient varying from 0.38 to 0.51 ; Table 3). Furthermore, in summer $75 \%$ of all resting sites used by males were located near the edges of their home ranges, close to female home ranges (Fig. 4). The exception was a young male M7, whose home range strongly overlapped with a female's home range. In summer, resting sites of M7 were spatially clumped too, but mostly in central part of its home range (Fig. 4).

The average distance between consecutively used resting sites differed significantly between males $(690 \mathrm{~m}, \mathrm{SD}=531, n=801)$ and females $(419 \mathrm{~m}, \mathrm{SD}=422$, $n=364 ; t=-8.59, p<0.001)$. For males the average distance was smallest in 
Table 3. Comparison of distribution of different resting sites in individual marten's home range calculated by standardized Morisita coefficient of dispersion (Ip) in three seasons. Ip was calculated only for individual martens using more than 20 different resting site in one season.

\begin{tabular}{|c|c|c|c|c|c|c|}
\hline Martens & Year & $\begin{array}{c}\text { Number of } \\
\text { different } \\
\text { resting sites }\end{array}$ & Ip & $\chi^{2}$ & df & $p$ \\
\hline \multicolumn{7}{|c|}{ Spring } \\
\hline F9 & 1995 & 27 & 0.30 & 33.19 & 24 & ns \\
\hline F12 & 1995 & 22 & -0.24 & 24.54 & 31 & ns \\
\hline M3 & 1994 & 27 & 0.24 & 107.71 & 94 & ns \\
\hline M4 & 1991 & 24 & 0.40 & 56.50 & 41 & ns \\
\hline M5 & 1992 & 21 & 0.34 & 78.00 & 62 & ns \\
\hline M5 & 1995 & 38 & 0.46 & 99.79 & 76 & 0.03 \\
\hline M7 & 1995 & 31 & 0.28 & 80.87 & 67 & $\mathrm{~ns}$ \\
\hline \multicolumn{7}{|c|}{ Summer } \\
\hline F6 & 1992 & 29 & 0.50 & 109.55 & 81 & 0.02 \\
\hline $\mathrm{F} 12$ & 1995 & 38 & 0.38 & 45.37 & 32 & ns \\
\hline M3 & 1994 & 25 & 0.39 & 98.24 & 78 & $\mathrm{~ns}$ \\
\hline M4 & 1991 & 56 & 0.50 & 132.57 & 95 & 0.007 \\
\hline M5 & 1994 & 38 & 0.50 & 103.63 & 68 & 0.003 \\
\hline M5 & 1995 & 50 & 0.50 & 119.36 & 89 & 0.018 \\
\hline M7 & 1995 & 32 & 0.51 & 75.50 & 42 & 0.001 \\
\hline \multicolumn{7}{|c|}{ Autumn-winter } \\
\hline F6 & $1991 / 92$ & 23 & 0.06 & 41.35 & 39 & ns \\
\hline F11 & $1995 / 96$ & 23 & 0.50 & 92.43 & 58 & 0.003 \\
\hline $\mathrm{F} 12$ & 1995/96 & 35 & -0.05 & 27.57 & 29 & $\mathrm{~ns}$ \\
\hline M3 & $1993 / 94$ & 29 & 0.24 & 117.50 & 103 & $\mathrm{~ns}$ \\
\hline M3 & $1994 / 95$ & 36 & 0.50 & 225.33 & 146 & 0.001 \\
\hline M4 & 1991/92 & 31 & 0.31 & 70.13 & 56 & ns \\
\hline M5 & $1994 / 95$ & 43 & 0.50 & 69.74 & 47 & 0.017 \\
\hline M5 & $1995 / 96$ & 42 & 0.30 & 95.14 & 79 & $\mathrm{~ns}$ \\
\hline M7 & $1994 / 95$ & 43 & 0.50 & 93.39 & 68 & 0.022 \\
\hline M10 & $1994 / 95$ & 27 & -0.04 & 79.30 & 81 & $\mathrm{~ns}$ \\
\hline
\end{tabular}

February-March and largest in August-September (variation between six 2 -month periods, ANOVA $F=6.66, p<0.001$ ) (Fig. 5), whereas for females the shortest distances were recorded in April-May, when they were with young (ANOVA $F=3.38, p=0.005$ ). In autumn-winter, the average distance between male resting sites depended on the male's body mass, with larger males often choosing resting sites farther apart than those of smaller males (Fig. 6). A similar relation was found in spring but not in summerm (Fig. 6).

In winter, $21.2 \%$ of consecutive resting site relocations were in the same place (total $n=590$ day to day relocations). During periods of lower temperatures males often returned to or stayed in the same resting places for the following day. 


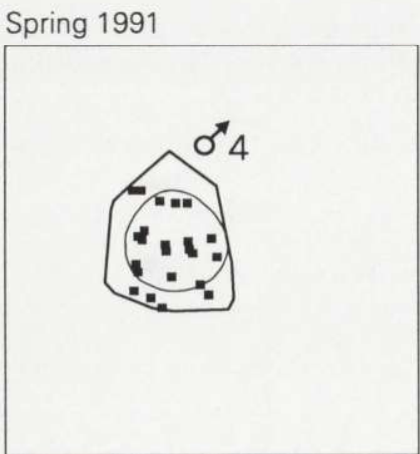

Summer 1991

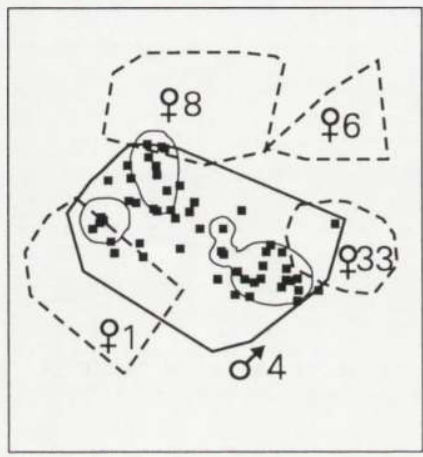

Autumn-winter 1991/92

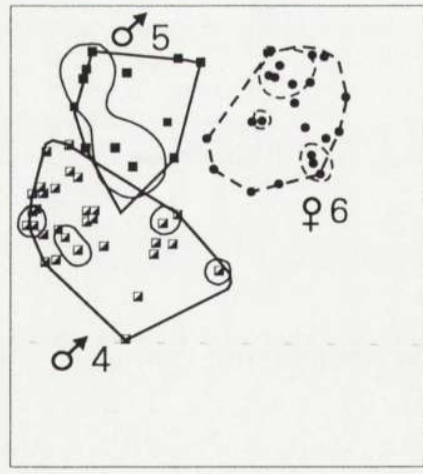

Males

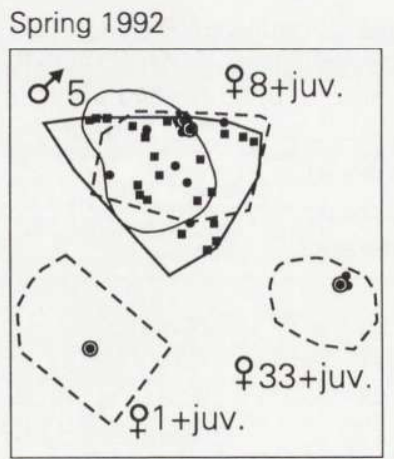

Summer 1992

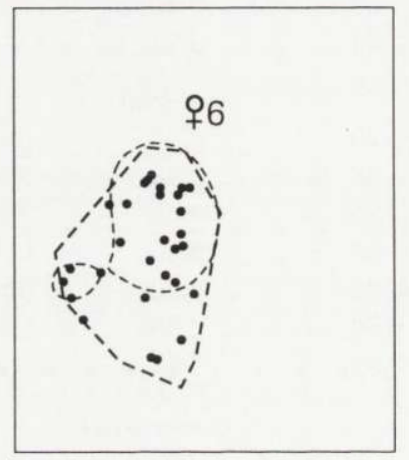

Autumn-winter 1992/93

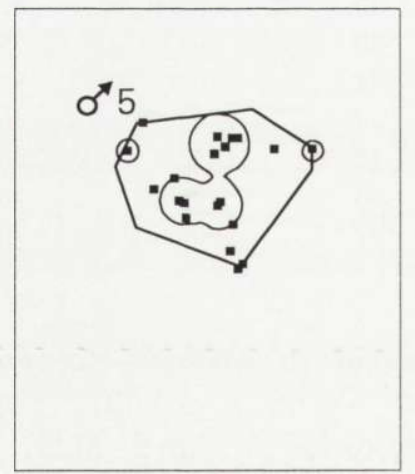

Autumn-winter 1993/94

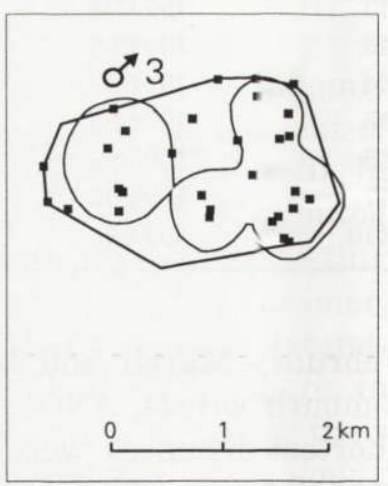

Spring 1993

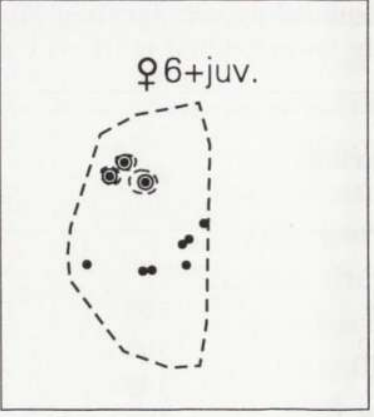

Summer 1993

no data

$\sigma^{7}$ - radiotracked individuals MCP home range

$75 \%$ Kerne range

esting sites

Fig. 4. Distribution of different resting sites within home ranges of male and female pile martens. localizations of martens in resting sites. In summer, distribution of male resting sites is ompared to snow tracking carried out in winter. 
Spring 1994

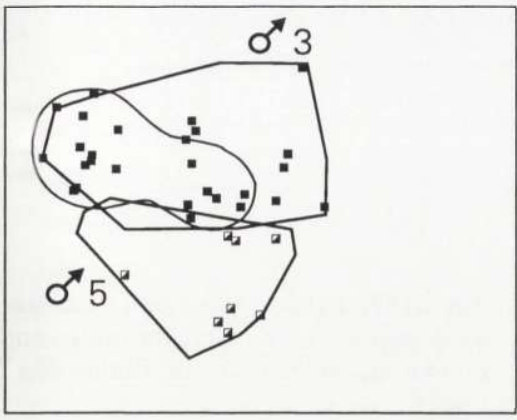

Summer 1994

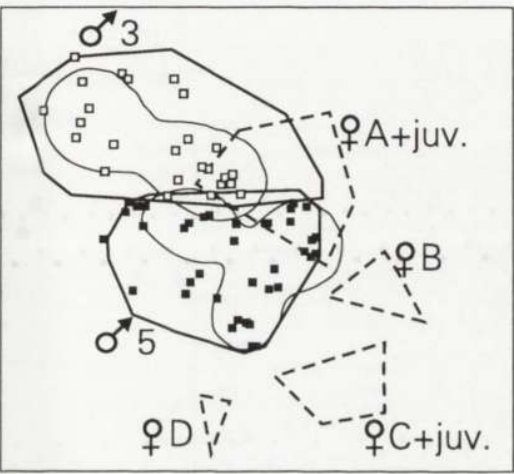

Autumn-winter 1994/95

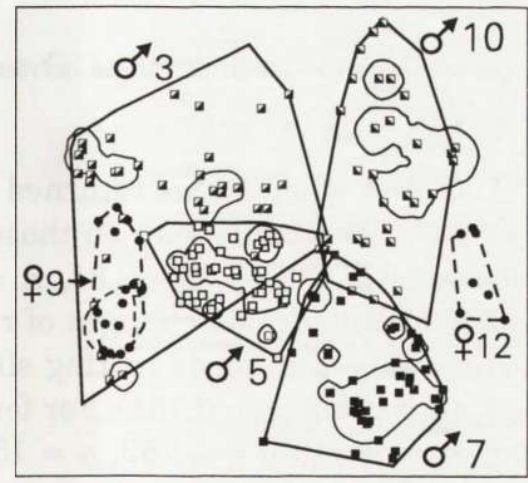

Females
Spring 1995

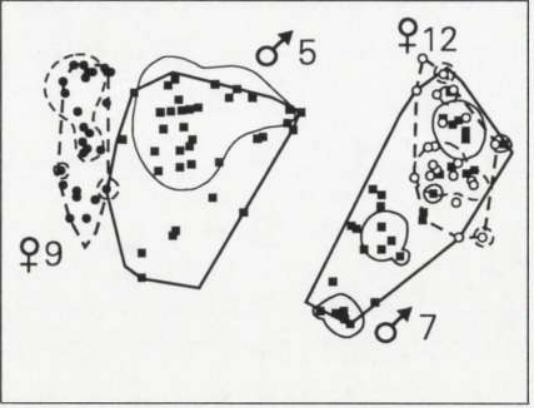

Summer 1995

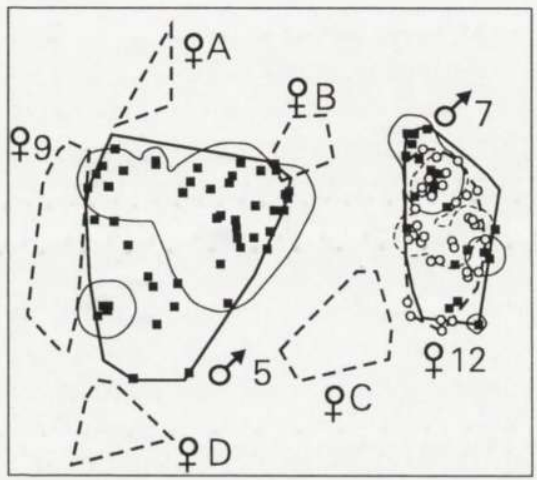

Autumn-winter 1995/96

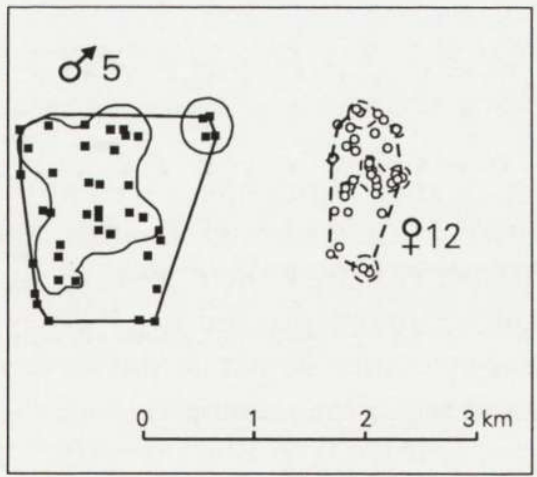

$3 \mathrm{~km}$
\$12- radiotracked individuals
--- - MCP home range
$75 \%$ Kerne range
A - snow tracked individuals
$\bullet \quad$ - resting sites
- - den with young

treas with most frequently used resting sites were calculated by Kernel method with $75 \%$ of all ocation of female home ranges. In 1994 and 1995 female distributions were determined according to 


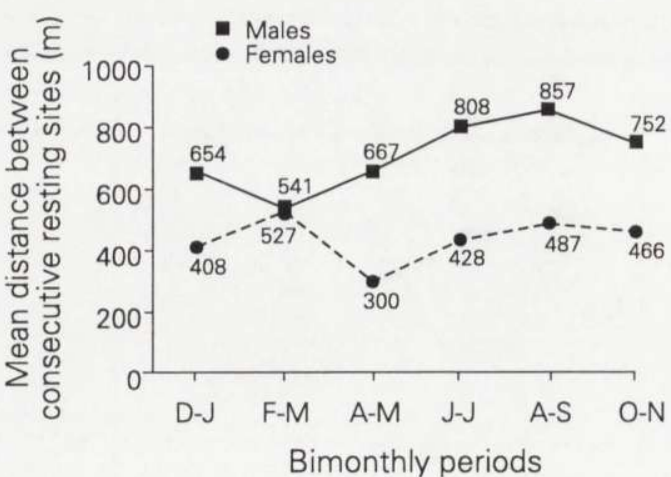

Fig. 5. Changes in the mean distance between consecutive resting sites for males and females in two-month periods in Białowieża National Park.
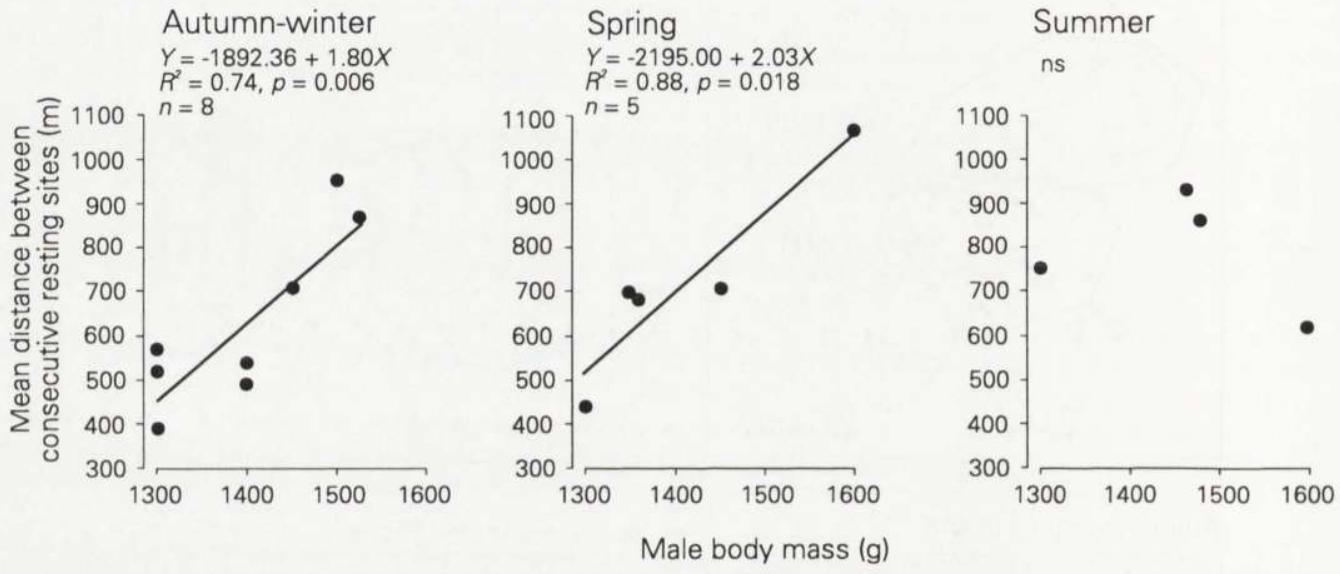

Fig. 6. Relationship between body mass of male pine martens and the mean distances between their consecutive resting sites.

Daytime temperatures (measured at $07.00 \mathrm{~h}$ ) on days when males returned to the same resting site were significantly lower $\left(-2.3^{\circ} \mathrm{C}, \mathrm{SD}=6.23\right)$ than on those days when males changed their resting sites $\left(-0.6^{\circ} \mathrm{C}, \mathrm{SD}=4.76, \mathrm{t}=2.84, n=438\right.$, $p=0.005$ ). Snow depth did not have a significant influence on changes of resting site. Average snow depth on days when martens stayed in same resting site was $5.2 \mathrm{~cm}$ and when they changed $-3.5 \mathrm{~cm}(t=-1.44, n=438, p=0.151)$. For females, both temperature $(t=1.56, n=152, \mathrm{~ns})$ and snow depth $(t=-1.53, n=152, \mathrm{~ns})$ were unimportant in the choice of resting sites.

\section{Social aspects of resting site use}

Individuals of the same sex whose home ranges overlapped, did not use the same resting site during the same season. Male-male home range overlap was recorded in five cases during winter, once in spring and once in summer, and female-female home range overlap was recorded only once, during summer. The 
Table 4. Number of different resting sites (in parentheses: number of days spent in them) used by males and females whose home ranges overlapped. Column 'Both' lists the number of resting sites that were utilised by both a male and a female but not necessarily on the same day.

\begin{tabular}{|c|c|c|c|c|c|}
\hline \multirow{2}{*}{ Martens } & \multirow{2}{*}{ Year } & \multirow{2}{*}{$\begin{array}{c}\text { Percent } \\
\text { home range } \\
\text { overlap }\end{array}$} & \multicolumn{3}{|c|}{ Number of resting site utilised by: } \\
\hline & & & Males & Females & Both \\
\hline \multicolumn{6}{|c|}{ Spring } \\
\hline M5 - F8 & 1992 & $40-100$ & $21(32)$ & $11(41)$ & - \\
\hline M5 - F6 & 1993 & $0-20$ & $10(12)$ & $11(38)$ & - \\
\hline $\mathrm{M} 3-\mathrm{F} 8$ & 1994 & $0-20$ & $27(33)$ & $10(16)$ & - \\
\hline M3 - F1 & 1994 & $0-20$ & $27(33)$ & $5(9)$ & - \\
\hline M5 - F9 & 1995 & $0-20$ & $38(59)$ & $27(54)$ & - \\
\hline M7 - F12 & 1995 & $20-40$ & $31(58)$ & $22(50)$ & $3(14)$ \\
\hline \multicolumn{6}{|c|}{ Summer } \\
\hline $\mathrm{M} 5-\mathrm{F} 6$ & 1992 & $0-20$ & $6(6)$ & $29(31)$ & - \\
\hline M5 - F9 & 1995 & $0-20$ & $50(72)$ & $2(2)$ & - \\
\hline $\mathrm{M} 7-\mathrm{F} 12$ & 1995 & $40-100$ & $32(48)$ & $38(61)$ & $7(21)$ \\
\hline \multicolumn{6}{|c|}{ Autumn-winter } \\
\hline $\mathrm{M} 4-\mathrm{F} 6$ & $1991 / 92$ & $0-20$ & $31(94)$ & $23(52)$ & - \\
\hline $\mathrm{M} 3-\mathrm{F} 8$ & $1993 / 94$ & $0-20$ & $29(46)$ & $3(5)$ & - \\
\hline M5 - F8 & $1993 / 94$ & $40-100$ & $7(11)$ & $3(5)$ & - \\
\hline M3 - F9 & $1994 / 95$ & $40-100$ & $36(98)$ & $14(25)$ & $2(2)$ \\
\hline
\end{tabular}

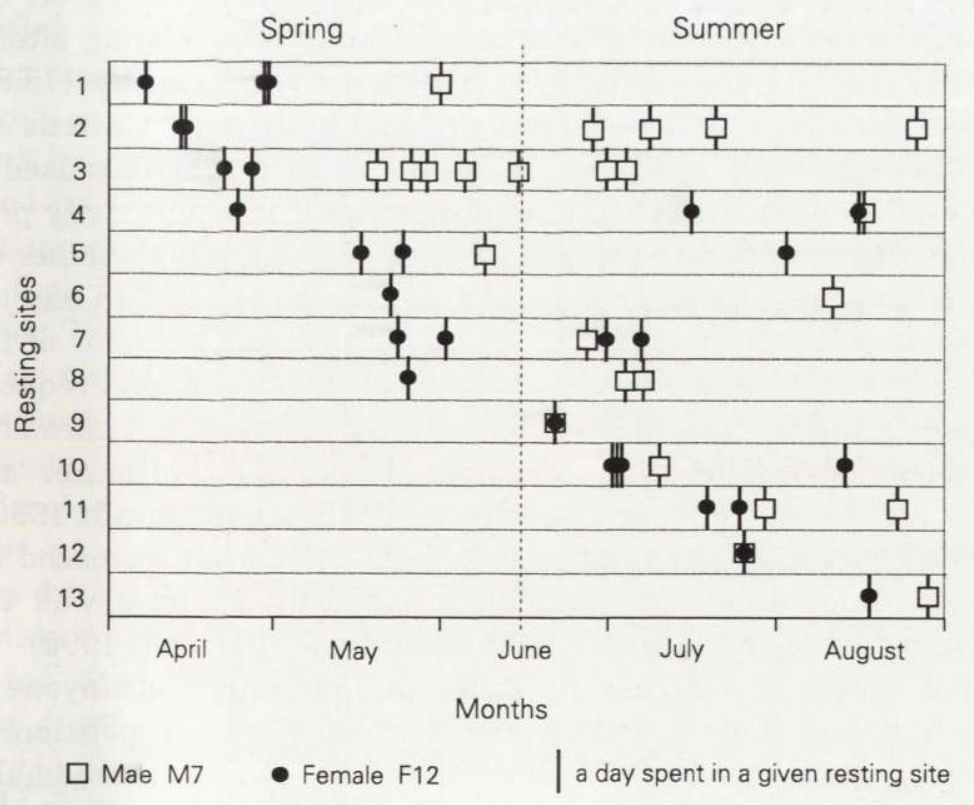

Fig. 7. Pattern of usage of 13 resting sites by male M7 and female F12 in spring and summer months. Consecutive numbers (1-13) indicate different resting sites used by both individuals. 
use of the same resting site in same season by males and females was recorded in only one case in winter and only two resting sites were used by individuals of both sexes (Table 4). In spring the use of the same resting site by males and females was recorded only in a young male $(<2$ years $)$ and an old female $(>2$ years old) but not in the same resting site at the same time (Table 4, Fig. 7). In summer, more frequently than in other seasons, the young male chose resting sites which were previously used by a female and the time from a day when the female used a resting site to a day when the male chose that same place was shorter. Martens of both sexes were found in one resting site at the same time or the day after from mid-June to mid-August. Females did not use resting sites used previously by males during any season. It was always the other way round.

\section{Discussion}

Several studies support the view that the number of available setts or resting sites can affect population size, home range size and shape or social group size (Weber 1985, Doncaster and Woodroffe 1993, O'Corry-Crowe et al. 1993, Roper 1993, Halliwell and Macdonald 1996). Most of those investigations were about animals living in groups, whereas the pine marten is solitary. Their morphological adaptations to tree climbing (Yurgerson 1950) enable the marten use of arboreal resting sites. In Białowieża National Park over 95\% of all resting sites were arboreal (see Zalewski 1997). Amongst such sites, males used on average 86 different cavities in a year (44.9\% of a total number of resting sites per year, Zalewski 1997) and 91 nests (47.8\%). Females used 121 cavities (75.8\%) and 31 nests (19.3\%). The average home range was 223 ha in male martens and 149 ha in females (Zalewski et al. 1995). For males the density of cavities used for resting was one per 2.6 ha of home range and for females it was one cavity per 1.2 ha of a home range. It is difficult to explain why martens use a big number of different resting sites which at the same time are situated very close to one another. In polecat Mustela putorius it could be a result of nomadic behavior of this species (Weber 1989) but in my study area most martens were resident. Frequent changes of resting sites could be explained by defensive strategy against parasites. Similar strategy was suggested for other predators (King 1976, Palomares and Delibes 1993, Butler and Roper 1996) and squirrels (Wauters and Dhondt 1990). The fact that the number of different resting sites used by marten increased in summer when parasite infestations in Mustelidae and squirrel dreys was the highest confirms this hypothesis (Sleeman 1989, Wauters and Dhondt 1990).

The small percentage of use by different individuals of anyone particular resting site suggests that, in Białowieża National Park, competition for resting site either does not occur or is very low. The fact, however, that females avoided resting site used by males tends to confirm Powell's (1993) hypothesis that spacing pattern is imposed by males on females. However, in stone marten Martes foina 
other behaviour was observed: a female expelled a male from a resting site (Skirnisson 1986).

In both sexes there were seasonal differences in the choice of the type of resting site (Zalewski 1997) as well as the patterns of their use. In summer, martens used a large number of different resting sites; $99.2 \%$ of sites were in trees and $6.4 \%$ of these were simply on branches (Zalewski 1997). Males, whose home ranges did not overlap extensively with those of females, used resting sites close to the female's home range border. The older males and females did not rest together at one resting site. Copulations occur early in the morning ( 05.00 to $10.00 \mathrm{~h}$ ) or in the evening ( 17.00 to $21.00 \mathrm{~h}$ ) (Ocetkiewicz 1973). In summer males often finished their activities about $07.00-09.00 \mathrm{~h}$, then returned to their home range and quickly found a resting site close to the edge of the female's home range border. In evening, males usually began moving at $17.00 \mathrm{~h}$ and, if they were resting close to a female, they would easily find a receptive one. In summer distance between the consecutive resting sites was greatest in a year which corresponds with increased home range size and daily movement distance in marten (A. Zalewski and W. Jędrzejewski, in prep.). Males that move further may visit more than one female during a night. Longer distances between resting sites can decrease the time of male's travel to females which are distributed on the edges of males' home ranges. Distance between the consecutive resting sites was independent of body mass of males, but rather depended on female home range distribution. The availability of resting sites close to female home ranges may influence the mating success of adult males.

Young males followed a different reproductive strategy. Their home ranges largely overlap with that of a female and they used female resting sites or both a male and a female used the same resting site simultaneously. This reproductive tactic, alternative to that of older males, can increase the mating success of young males. A link between different mating tactics amongst males and their body mass was recorded for the Egyptian mongoose Herpestes ichneumon (Palomares 1993). The largest males had contact with at least 4 females but spent little time with each individual. Smaller males had contact with only one female, but spent more time with her (Palomares 1993). The two mating tactics found in the pine marten were similar to the roaming and stationary mating tactics reported in stoat Mustela erminea (Sandell 1986). But in contrast to stoat, older pine marten males extended their home range only a little during the mating season (A. Zalewski and W. Jędrzejewski, in prep.) and did not roam over extensive areas.

In winter martens have to reduce heat losses. They select better insulated resting sites during spells of low temperature (Buskirk et al. 1989, Brainerd et al. 1995, Zalewski 1997), and therefore change their summer pattern of resting site use. In winter they often returned to the known sites which were probably better insulated or close to the food (ungulate carcasses). In autumn-winter ungulate carcass were important alternative sources of food for the marten (Pulliainen 1981, Jędrzejewski et al. 1993). However, this pattern changed during periods of deep snow so that martens returned to the known resting sites less often. A possible 
explanation of this is that, if martens were to return to more distant resting sites, energy loss would be higher than finding a new resting site closer to where they finished their foraging activities. This energy loss could explain reduced consumption of carcasses with increasing snow depth which was noted before (Zalewski et al. 1995). However, during days when temperatures were very low and/or snow very deep, the marten often stayed in the same resting site for the following day. This behavior, during which martens reduced their activities or were inactive all day in very low temperature was previously observed in taiga forests in north-eastern Europe (Grakov 1981). This long period of inactivity without food for animals like martens, with a very high lower critical temperature (for American marten $16^{\circ} \mathrm{C}$, Buskirk et al. 1988) and with a relatively high basal metabolism rate (Iversen 1972), can decrease marten survival. Two explanations can help to solve this problem. First, marten can catch more prey during lower temperatures and store them. Surplus killing behavior linked to the ambient temperature has been observed in weasel Mustela nivalis (Jędrzejewska and Jędrzejewski 1989). Secondly, marten may have to prey on bigger animals in severe winter conditions, especially in high snow cover which decreases accessibility of rodents (Jędrzejewski et al. 1993). Squirrels Sciurus vulgaris (an average weight of $300 \mathrm{~g}$ ), were found to comprise a relatively higher percentage of marten diets in both of the harshest winters studied (1985/1986 and 1995/1996; Jędrzejewski et al. 1993 and A. Zalewski, unpubl.). In other winters they were found only occasionally in the diet probably because squirrels are very agile and often escape. In severe winters, when squirrel decreases activity (Gurnell 1987), martens probably capture them in dreys (Pulliainen and Ollinmäki 1996). A link between the latitude (as an indicator of winter severity) and average prey size has not been found for the pine marten (Clevenger 1994). Nevertheless, a relationship between latitude and the percent of big birds (tetraonid) in marten diet was found by Jędrzejewski et al. (1993). With such bigger prey (squirrel, hare Lepus sp. or tetraonid birds) martens can reduce activity and rest at the same site for an additional day.

In conclusion, the pattern of resting site use by pine marten was different in the reproductive and non-reproductive season. During the reproductive season, females' behaviour in utilisation of resting sites reflected their need to care for young, whereas the pattern of site utilisation by males reflected mostly the dispersion of females. Also, this work shows variation in resting site use based on the flexibility of male mating tactics. In non-reproductive seasons the pattern of resting site use by pine marten was influenced by heat loss, the energy budget and diet composition.

Acknowledgements: I wish to thank the technical staff of MRI (E. Bujko and K. Zub), students of Farnborough College of Technology (England) for their help in the field work. I am grateful to Prof Z. Pucek for granting me his unpublished data. K. Zub helped in preparation of figures. I am grateful to Prof Z. Pucek, J. A. Bisonette, Dr B. Jędrzejewska and two anonymous referees for comments on an earlier draft. The study was supported by KBN 6 P205 08006 grant and partly by Mammal Research Institute PAS budget. 


\section{References}

Beja P. R. 1996. Temporal and spatial patterns of rest-site use by four female otters Lutra lutra along the south-west coast of Portugal. Journal of Zoology, London 239: 741-753.

Brainerd S. M., Helldin J. O., Lindström E. R., Rolstad E., Rolstad J. and Storch I. 1995. Pine marten (Martes martes) selection of resting and denning sites in Scandinavian managed forests. Annales Zoologici Fennici 32: 151-157.

Buskirk S. W., Forrest S. C., Raphael M. G. and Harlow H. J. 1989. Winter resting site ecology of marten in the Central Rocky Mountains. Journal of Wildlife Management 53: 191-196.

Buskirk S. W., Harlow H. J. and Forrest S. C. 1988. Temperature regulation in American marten (Martes americana) in winter. National Geographic Research 4(2): 208-218.

Butler J. M. and Roper T. J. 1996. Ectoparasites and sett use in European badgers. Animal Behaviour 52: 621-629.

Clevenger A. P. 1994. Feeding ecology of Eurasian pine martens and stone martens in Europe. [In: Martens, sables, and fishers: Biology and conservation. S. W. Buskirk, A. S. Harestad, M.G.Raphael and R. A. Powell, eds]. Cornell University Press, Ithaca, London: 326-340.

Doncaster C. P. and Woodroffe R. 1993. Den site can determine shape and size of badger territories: implications for group-living. Oikos 66: 88-93.

Faliński J. B. 1986. Vegetation dynamics in temperate lowland primeval forest. Dr. W. Junk Publishers, Dordrecht: 1-537.

Goszczyński J. 1974. Studies on the food of foxes. Acta Theriologica 19: 1-18.

Grakov N. N. 1981. [The pine marten]. Nauka, Moskva: 1-109. [In Russian]

Gurnell J. 1987. The natural history of squirrels. Christopher Helm, London: 1-201.

Halliwell E. C. and Macdonald D. W. 1996. American mink Mustela vison in the Upper Thames catchment: relationship with selected prey species and den availability. Biological Conservation 76: $51-56$.

Iversen J. A. 1972. Basal energy metabolism of mustelids. Journal Comparative Physiology 81: 341-344.

Jędrzejewska B. and Jędrzejewski W. 1989. Seasonal surplus killing as hunting strategy of the weasel Mustela nivalis - test of a hypothesis. Acta Theriologica 34: 347-359.

Jędrzejewski W., Zalewski A. and Jędrzejewska B. 1993. Foraging by pine marten Martes martes in relation to food resources in Białowieża National Park, Poland. Acta Theriologica 38: 405-426.

King C. M. 1976. The fleas of a population of weasels in Wytham Woods, Oxford. Journal of Zoology, London 180: 525-535.

Krebs C. J. 1989. Ecological methodology. Harper Collins Publishers, New York: 1-654.

Lindström E. R., Brainerd S. M., Helldin J. O. and Overskaug K. 1995. Pine marten - red fox interactions: a case of intraguild predation? Annales Zoologici Fennici 32: 123-130.

Lockie J. D. 1959. The estimation of the food of foxes. Journal of Wildlife Management 23: 224-227.

Marchesi P. 1989. Ecologie et comportement de la martre (Martes martes L.) dans le Jura Suisse. Ph D thesis, Université de Neuchâtel, Institute de Zoologie, Neuchâtel: 1-185.

Ocetkiewicz J. 1973. [Results of pine marten (Martes martes L. 1758) breeding in captivity]. Wydawnictwa Własne Instytutu Zootechniki 351: 1-48. [In Polish]

O'Corry-Crowe G., Eves J. and Hayden T. J. 1993. Sett distribution, territory size and population density of badgers (Meles meles L.) in east Offaly. [In: The badger. T. J. Hayden, ed]. Royal Irish Academy, Dublin: 35-56.

Okarma H., Jędrzejewski W., Schmidt K., Kowalczyk R. and Jędrzejewska B. 1997. Predation of Eurasian lynx on roe deer and red deer in Białowieża Primeval Forest, Poland. Acta Theriologica 42: $203-224$.

Olszewski J. L. 1986. The role of forest ecosystems in modifying local climate of the Białowieża Primeval Forest, as revealed by air temperature characteristics. Wydawnictwo PAN (Prace habilitacyjne), Ossolineum, Wrocław: 1- 222. [In Polish with English summary] 
Palomares F. 1993. Individual variations of male mating tactics in Egyptian mongooses (Herpestes ichneumon): can body mass explain the differences? Mammalia 57: 317-324.

Palomares F. and Delibes M. 1993. Resting ecology and behaviour of Egyptian mongooses (Herpestes ichneumon) in southwestern Spain. Journal of Zoology, London 230: 557-566.

Powell R. A. 1993. Why do some forest carnivores exhibit intersexual territoriality and what are the consequences for management? [In: Proceeding of the International Union of Game Biologists XXI Congress, Halifax, Nova Scotia, Canada, August 15-20, 1993. I. D. Thompson, ed]. Petawawa National Forestry Institute, Halifax, vol. 1: 268-271.

Pucek Z., Jędrzejewski W., Jędrzejewska B. and Pucek M. 1993. Rodent population dynamics in a primeval deciduous forest (Białowieża National Park) in relation to weather, seed crop, and predation. Acta Theriologica 38: 199-232.

Pulliainen E. 1981. Food and feeding habits of the pine marten in Finnish Forest Lapland in winter. [In: Worldwide Furbearer Conference Proceedings. J. A. Chapman and D. Purseley, eds]. Frostburg, Maryland, USA: 580-598.

Pulliainen E. and Ollinmäki P. 1996. A long-term study of the winter food niche of the pine marten Martes martes in northern boreal Finland. Acta Theriologica 41: 337-352.

Roper T. J. 1993. Badger setts as a limiting resource. [In: The badger. T. J. Hayden, ed]. Royal Irish Academy, Dublin: 26-34.

Sandell M. 1986. Movement patterns of male stoats Mustela erminea during mating season: differences in relation to social status. Oikos 47: 63-70.

Skirnisson K. 1986. Untersuchungen zum Raum-Zeit-System freilebender Steinmarder (Martes foina Erxleben, 1777). $\mathrm{Ph} \mathrm{D}$ thesis, Institut für Haustiekunde an der Universität Kiel/Forschungsstelle Wildbiologie, Kiel: 1-200.

Sleeman D. P. 1989. Ectoparasites of the Irish stoat. Medical and Veterinary Entomology 3: 213-218.

Wauters L. A. and Dhondt A. A. 1990. Nest-use by red squirrels (Sciurus vulgaris Linnaeus, 1758). Mammalia 54: 377-389.

Weber D. 1985. Den use by foxes (Vulpes vulpes L.) and its function. Zeitschrift für Säugetierkunde 50: $356-368$.

Weber D. 1989. The ecological significance of resting sites and the seasonal habitat change in polecats (Mustela putorius). Journal of Zoology, London 217: 629-638.

Yurgenson P. B. 1950. [A study on comparative ecology of genus Martes]. Ph D thesis, Gosudarstvennyi Universitet M. V. Lomonosova, Moskva: 1-7. [In Russian]

Zalewski A., Jędrzejewski W. and Jędrzejewska B. 1995. Pine marten home ranges, numbers and predation on vertebrates in a deciduous forest (Białowieża National Park, Poland). Annales Zoologici Fennici 32: 131-144.

Zalewski A. 1997. Factors affecting selection of resting site type by pine marten in primeval deciduous forests (Białowieża National Park, Poland). Acta Theriologica 42. (in press)

Zielinski W. J., Spencer W. D. and Barrett R. H. 1983. Relationship between food habits and activity patterns of pine martens. Journal of Mammalogy 64: 387-396.

Received 3 September 1996, accepted 31 March 1997. 